\title{
Asimetri informasi dalam transaksi perbankan syariah di Indonesia
}

\author{
Slamet Haryono \\ UIN Sunan Kalijaga Yogyakarta \\ E-mail:selahary@gmail.com
}

This study employs the assymmetric information in the Indonesian shariah banking. Assymmetric information in the banking sector contains: moral hazard, adverse selection. Moral hazard is a situation in which one agent decides on how much risk to take, while another agent bears (parts of) the negative consequences of risky choices. The uncertainty surrounding any bank decisions. The market does not get information about the riskiness of a bank. Asymmetric information problems exist in the bank loan market. Depositors cannot distinguish the risk, they deposit their funds in those banks that offer the highest rates and make the most risky investments. Our result points towards regulator to enhancing transparency may be useful to reduce incentives for excessive assymmetric information of sharia banking.

Penelitian ini membahas tentang informasi asimetrik dalam perbankan Syariah di Indonesia. Informasi asimetrik dalam dunia perbankan terdiri dari: moral hazard dan adverse selection. Moral hazard adalah suatu kondisi di mana seorang agen memutuskan sejauh mana resiko akan dihadapi, sementara itu agen menanggung konsekuensi-konsekuensi negatif atas pilihan-pilihan yang beresiko. Ketidakpastian akan selalu menyertai keputusan bank. Pasar tidak memperoleh informasi mengenai risiko yang dihadapi bank. Problem informasi asimetrik terdapat di dalam pasar pinjaman bank. Para depositor tidak dapat memastikan risiko yang akan dihadapi, mereka menanamkan dana mereka di bank-bank yang menawarkan keuntungan tertinggi dan memilih investasi yang beresiko tinggi. Hasil rekomendasi kami kepada penguasa untuk memperjelas transparansi yang berguna untuk mengurangi insentif bagi informasi asimetris yang berlebihan di perbankan syariah.

Keywords: Sharia; Banking; Assymmetric; Information 
ljtihad, Jurnal Wacana Hukum Islam dan Kemanusiaan, Volume 15, No. 1, Juni 2015: 103-118

\section{Pendahuluan}

Tulisan ini mengkaji terjadinya asimetri informasi dalam transaksi perbankan syariah. Ketidaksetaraan informasi terlihat antara pelaku bisnis untuk mendapatkan laba dengan posisi konsumen untuk mendapatkan kepuasan melalui pemenuhan kebutuhannya terhadap produk tersebut. Undang-Undang No.8 Tahun 1999 tentang Perlindungan Konsumen bertujuan untuk menyeimbangkan daya tawar konsumen dengan bank sebagai penyedia produk dan mendorong bank untuk selalu jujur serta bertanggungjawab dalam menjalankan usahanya. Nasabah biasanya berada pada posisi tawar menawar yang lemah dan karenanya dapat menjadi sasaran eksploitasi dari pelaku bisnis yang secara sosial ekonomi memiliki posisi kuat, khususnya dalam hal pelaku bisnis atau bank menggunakan perjanjian baku

Data Industri keuangan syariah di Indonesia yang diterbitkan Otoritas Jasa Keuangan perseptember 2014 dengan pangsa pasar 5\% - 7\% pada tahun 2014 seperti tabel berikut ini;

\section{Tabel 1.}

\begin{tabular}{|lr|}
\hline \multicolumn{2}{|c|}{ Jaringan Kantor Perbankan Syariah } \\
\hline \multicolumn{1}{|c|}{ Jumlah } & Sep-14 \\
\hline Bank Umum Syariah & 11 \\
- Jumlah Bank & 2,139 \\
$\quad$ Jumlah Kantor & \\
Unit Usaha Syariah & 23 \\
- Jumlah Bank Umum & \\
Konvensional yang memiliki UUS & 425 \\
& \\
- Jumlah Kantor & 163 \\
Bank Pembiayaan Rakya: Syariahn & 433 \\
- Jumlah Bank & $\mathbf{2 , 9 9 7}$ \\
\hline
\end{tabular}

Di sisi lain, kasus-kasus yang merugikan nasabah masih sering terjadi. Sebagai contoh pada 21 Juni 2012 adanya uang nasabah yang hilang di kantor Bank CIMB Niaga Syariah Kota Padang (Republika online, 2012: 1). Kasus lain yaitu Pembiayaan Fiktif di Bank Syariah Mandiri Bogor yang melibatkan pegawainya. Kasus selanjutnya yaitu kasus Gadai Emas yang melibatkan Bank Mega Syariah. 
Bank berdasarkan prinsip syariah atau bank syariah, seperti halnya bank konvensional, juga berfungsi sebagai suatu lembaga intermediasi (intermediary institution), yaitu mengerahkan dana dari masyarakat dan menyalurkan kembali dana-dana tersebut kepada masyarakat yang membutuhkannya dalam bentuk fasilitas pembiayaan. Bedanya hanyalah bahwa bank syariah melakukan usahanya tidak berdasarkan bunga (interest free), tetapi berdasarkan prinsip syariah, yaitu prinsip pembagian keuntungan dan kerugian (profit and loss sharing principle atau PLS Principles) (Syahdeini, 1999: 1).

Hak-hak bank syariah sebagai produsen jasa lebih menonjol dibandingkan dengan hakhak konsumen, karena syarat-syarat atau klausul-klausul dalam perjanjian tersebut, lebih "tampak" dari sisi kewajiban konsumen. Dengan demikian, hak dan kewajiban antara produsen dan konsumen kurang seimbang atau belum setara. Praktek semacam ini banyak terdapat dalam perusahaan-perusahan yang belum sepenuhnya menciptakan keseimbangan antara posisi perusahaan (pendapatan) dan konsumen berupa peningkatan pelayanan dan perlindungan hukum yang sesuai dengan harapan konsumen. Banyak kasus yang terjadi akibat adanya asimetri informasi atau ketidaksetaraan pengetahuan dan kekuatan tawar (Thadden, 2001: 2). Kasus penjualan produk derivatif Bank Danamon kepada nasabah (Unit Usaha Syariah) Bank Danamon menunjukkan lemahnya independensi unit usaha syariah terhadap bank konvensional yang memilikinya.

Alasan masyarakat menggunakan jasa perbankan syariah karena berbagai alasan. Masingmasing individu mempunyai tujuan yang hampir seragam yaitu antara lain menganggap bank syariah telah sesuai dengan syariah Islam dengan penerapan sistem bagi hasil, aman, menguntungkan, dekat atau mudah dijangkau, dan alasan lain yang bersifat fasilitas (Priyanti, 2007: 2). Bank berkewajiban memenuhi harapan-harapan masyarakat tersebut. Namun, beberapa kejadian ternyata membuktikan sebaliknya.

Kejadian yang justru menunjukkan bahwa konsumen dirugikan atau dilanggar haknya atau bank tidak memenuhi kewajibannya. Tetapi, terdapat kesenjangan antara kualitas pelayanan yang diberikan Bank Syariah dengan yang diharapkan oleh nasabah pada semua dimensi kualitas pelayanan, yaitu prinsip syariah (compliance), keyakinan (assurance), keandalan (reliability), fisik nyata (tangible), empati (emphaty), dan daya tanggap (responsiveness) (Priyanti, 2007: 14). Di Indonesia, berdasarkan pengalaman dari Yayasan Lembaga Konsumen Indonesia 
ljtihad, Jurnal Wacana Hukum Islam dan Kemanusiaan, Volume 15, No. 1, Juni 2015: 103-118

(YLKI) selama berpuluh tahun beroperasi, masih banyak permasalahan yang dihadapi konsumen. Pengusaha dan pemerintah sering mengabaikan hak-hak konsumen, baik dalam pelayanan pada masyarakat (public service) maupun dalam penjualan produk.

\section{Asimetri informasi dalam perbankan syariah}

Asimetri informasi menjadi masalah besar dalam perbankan syariah. Asimetri informasi merupakan suatu keadaan di mana manajer memiliki akses informasi atas prospek perusahaan yang tidak dimiliki oleh pihak luar perusahaan (McDonald, 1994: 23). Masalah ketidaksetaraan informasi menyebakan dispersi masalah ikutan serius dunia perbankan (Thadden, 2001: 2) dengan munculnya beragam kasus perbankan syariah. Asimetri informasi dapat diantisipasi dan diminimalkan dengan mengungkapkan informasi yang lebih berkualitas (Ariccia, 1998: 3). Munculnya kasus-kasus perbankan disebabkan oleh pengungkapan informasi yang berkualitas buruk.

Babczuk (2003: 7) menggolongkan tipe asimetri informasi yaitu: 1) Adverse Selection:adalah asimetri informasi yang terjadi satu pihak atau lebih yang melangsungkan atau akan melangsungkan suatu transaksi usaha, atau transaksi usaha potensial memiliki informasi lebih atas pihak-pihak lain. Adverse selection terjadi karena beberapa orang seperti manajer perusahaan dan para pihak dalam (insiders) lainnya lebih mengetahui kondisi kini dan prospek ke depan suatu perusahaan daripada para investor luar; 2) Moral Hazard: adalah asimetri informasi yang terjadi ketika satu pihak yang melangsungkan atau akan melangsungkan suatu transaksi usaha atau transaksi usaha potensial dapat mengamati tindakan-tindakan mereka dalam penyelesaian transaksi-transaksi mereka sedangkan pihak-pihak lainnya tidak. Moral hazard dapat terjadi karena adanya pemisahan pemilikan dengan pengendalian yang merupakan karakteristik kebanyakan perusahaan besar.

Contoh pertama seperti dalam perjanjian akad penyimpanan uang antara bank dengan pemilik uang, jika dicermati pasal perpasal cenderung mengatur kewajiban nasabah, sedangkan bank syariah selalu berdalih akad, sehingga akad selalu menjadi senjata bagi bank tanpa memperhatikan kewajiban bank untuk menjelaskan setiap konsekuensi tanda tangan akad meskipun hal ini juga terjadi pada bank konvensional. Contoh kedua yaitu pada produk pembiayaan bank syariah. Pasal-pasal dalam akad pembiayaan juga mengikat atas konsekuensi 
keuangan pembiayaan bagi penerima pembiayaan atau "kreditur". Ditinjau dari substansi keuangan penerima pembiayaan adalah sama dengan terminologi kredit pada bank konvensional. Akad-akad seperti juga bank konvensional cenderung mengamankan keuntungan bagi bank.

\section{Asimetri informasi dan regulasi perlindungan nasabah perbankan syariah}

Guidelines for consumer protection Ayat 31 yang dikeluarkan oleh PBB (Perserikatan Bangsa Bangsa) menyatakan bahwa,

Governments should develop or encourage the development of general consumer education and information programmes, bearing in mind the cultural traditions of the people concerned. The aim of such programmes should be to enable people to act as discriminating consumers, capable of making an informed choice of goods and services, and conscious of their rights and responsibilities. In developing such programmes, special attention should be given to the needs of disadvantaged consumers, in both rural and urban areas, including low-income consumers and those with low or non-existent literacy levels (United Nation, 2012).

Regulasi tersebut memberikan pedoman yang melindungi nasabah atas pemahaman hak dan kewajibannya serta melindungi dari kerugian yang mungkin timbul termasuk konsumen dengan kemampuan pengetahuan yang terbatas di manapun berada. Pemerintah berkewajiban untuk menjamin konsumen termasuk bank syariah mendapatkan hak-haknya dari bank syariah termasuk hak atas informasi tentang risiko produk perbankan syariah.

Undang-undang No. 8 Tahun 1999 pasal 8 ayat 1 huruf b dan c tentang perlindungan konsumen, menyatakan bahwa: Pelaku usaha dilarang memproduksi dan/atau memperdagangkan barang dan/atau jasa yang: a) Tidak sesuai dengan berat bersih, isi bersih atau netto, dan jumlah dalam hitungan sebagaimana yang dinyatakan dalam label atau etiket barang tersebut; b) Tidak sesuai dengan ukuran, takaran, timbangan dan jumlah dalam hitungan menurut ukuran yang sebenarnya.

Pernyataan di atas secara implisit, perbankan syariah dilarang menjual produk yang konsumen tidak jelas atau tidak sesuai dengan janji awal yang disampaikan kepada nasabah saat awal sebelum akad. Informasi sebelum akad disepakati adalah label, sedangkan isi adalah selama masa pembiayaan atau penyimpanan dana di bank syariah. Perlu adanya 
ljtihad, Jurnal Wacana Hukum Islam dan Kemanusiaan, Volume 15, No. 1, Juni 2015: 103-118

upaya perlindungan terhadap risiko memadai dari kemungkinan kerugian akibat penggunaan produk tersebut, pencegahan kerugian dari ketidakpastian atas mutu, jumlah dan keamanan produk jasa tersebut.

Sesuai Undang-undang No.21 tahun 2008 yang mensyaratkan bank syariah menjunjung prinsip keadilan dalam setiap transaksinya sehingga hak nasabah harus dipenuhi apapun posisinya baik sebagai penabung juga sebagai penerima pembiayaan. Bank Indonesia membuat konstruksi perlindungan hukum nasabah dengan membuat program praktis perbankan melalui mekanisme perbankan. Perlidungan hukum melalui mekanisme perbankan syariah meliputi melalui penetapan standar penyusunan mekanisme pengaduan nasabah; adanya lembaga mediasi independen; dan peningkatan transparansi informasi produk perbankan dan edukasi bagi nasabah (Bank Indonesia, 2008).

Undang-undang Nomor 10 Tahun 1998 tentang Perbankan Pasal 1 angka 16 secara yuridis telah mengatur hubungan bank dengan nasabah sebagai konsumen pengguna jasa bank, sehingga dalam pasal 1 angka 16 telah ditegaskan tentang nasabah yang diartikan sebagai "pihak yang menggunakan jasa bank." Dalam pengertian nasabah di sini, termasuk pula pihak yang tidak memiliki rekening namun memanfaatkan jasa bank untuk melakukan transaksi keuangan (walk-in customer), "Nasabah Penyimpan" adalah nasabah yang menempatkan dananya di bank dalam bentuk simpanan berdasarkan perjanjian bank dengan nasabah yang bersangkutan (Bank Indonesia, 1998).

Hubungan bank dengan nasabah dibangun atas dasar kepercayaan, karena pada prinsipnya lembaga keuangan dipercaya oleh masyarakat yang disebut nasabah untuk menyimpan dananya agar nasabah merasa aman dan memperoleh keuntungan. Pengertian "simpanan" adalah dana yang dipercayakan oleh masyarakat kepada bank berdasarkan perjanjian penyimpanan dana dalam bentuk giro, deposito, sertifikat deposito, tabungan, dan/atau bentuk lainnya yang dipersamakan dengan itu. Jenis kegiatan penghimpunan dana masyarakat oleh bank syariah melalui berbagai akad seperti simpanan atau giro atau deposito dan bentuk lainnya yang dapat dipersamakan dengan itu.

Pasal 1 butir 11 UU No.10 Tahun 1998 tentang Perbankan menyebutkan bahwa dalam merealisir pengucuran pembiayaan atau pinjaman perbankan, dipergunakan sarana hukum oleh pihak debitur dan perbankan yaitu adanya perjanjian kredit atau pembiayaan, yang 
dalam kenyataannya telah dipersiapkan atau dibakukan oleh pihak perbankan, serta di dalamnya terkandung klausul eksemsi yang "memberatkan" debitur (Santoso, 2009).

Klausul eksemsi tersebut disusun secara kaku oleh bank dan petugas hanya mengatakan hal tersebut adalah prosedur formal dan mereka hanya melaksanakan tanpa ada kesempatan bersama menyusun isi perjanjian. Implikasinya yaitu bahwa adanya kecenderungan bahwa perjanjian merupakan legitimasi bagi bank dengan dalih telah menandatangani perjanjian dalam rangka untuk membebaskan tanggungjawab bank terhadap kerugian nasabah debitur baik untuk seluruhnya maupun sebagian, yang sebenarnya kerugian tersebut termasuk dalam lingkup tanggung jawab bank sendiri. Perjanjian berimplikasi mengikat bagi nasabah tetapi tidak menyebutkan konsekuensi hukum bagi bank.

Undang-undang Perbankan No. 10 Tahun 1998 bila diperhatikan dalam pasal-pasalnya tidak memberikan aturan dasar ataupun katakanlah sebagai rambu-rambu yuridis yang dapat menjadi pedoman dalam setiap pembuatan formulir perjanjian kredit tersebut, sehingga hal ini menimbulkan konsekuensi pada kerawanan penentuan hak dan kewajiban masing-masing pihak secara tidak berimbang. Perjanjian bank dengan nasabah juga perlu mengacu perangkat hukum lain yaitu UU No. 8 Tahun 1999 tentang Perlindungan Konsumen terhadap hubungan hukum antara bank dan debitur, yang menyelenggarakan perjanjian kredit bank yang mengandung klausul eksemsi tersebut. Perlunya menyandarkan pada asas-asas hukum perjanjian, doktrin, serta yurisprudensi untuk mendapatkan aspek-aspek perlindungan hukum bagi debitur atas penerapan klausul eksemsi. Otoritas penyusun perundang-undangan perlu melakukan reformasi terhadap undang-undang perbankan dan undang-undang perlindungan konsumen dengan adanya kesetaraan bank dan nasabah sehingga dapat memberikan kepastian hukum dan perlindungan hukum bagi nasabah.

Undang-undang Perbankan No. 10 Tahun 1998 bila diperhatikan dalam pasal-pasalnya tidak memberikan aturan dasar ataupun katakanlah sebagai rambu-rambu yuridis yang dapat menjadi pedoman dalam setiap pembuatan formulir perjanjian pembiayaan tersebut, sehingga hal ini menimbulkan konsekuensi pada kerawanan penentuan hak dan kewajiban masingmasing pihak secara tidak berimbang. Di samping itu, perangkat hukum UU No. 8 Tahun 1999 tentang Perlindungan Konsumen juga perlu kiranya dijadikan sebagai acuan apakah dapat menjangkau terhadap hubungan hukum antara bank dan debitur, yang menyelenggara- 
ljtihad, Jurnal Wacana Hukum Islam dan Kemanusiaan, Volume 15, No. 1, Juni 2015: 103-118

kan perjanjian kredit bank yang mengandung klausul eksemsi tersebut.

Pencarian aspek-aspek perlindungan hukum perlu bagi debitur atas penerapan klausul eksemsi untuk meminimalisir kesenjangan (Santoso, 2009). Perubahan sistem perbankan harus dikawal dengan regulasi oleh hukum di satu pihak, sementara adanya pengawasan oleh sistem perbankan itu sendiri di lain pihak. Pengawasan dilakukan oleh Bank Indonesia sebagai Bank Sentral. Tujuan dari pengawasan adalah adanya jaminan pemenuhan ketaatan pada prinsip syariah dalam seluruh aktivitas bank. Sejak tahun 1992, dimulai dengan UU No. 7 Tahun 1992 sampai dengan terbitnya UU No. 21 Tahun 2008 telah terjadi proses perubahan pada regulasi perbankan. Salah satu bagian yang penting dalam regulasi itu adalah perlindungan terhadap nasabah Bank Syariah.

Sarana hukum yang harus dipergunakan oleh pihak debitur dan perbankan sebagaimana dimaksud oleh Pasal 1 butir 11 UU No. 10 Tahun 1998 tentang Perbankan, adalah perjanjian kredit itu sendiri, yang dalam kenyataannya telah dipersiapkan atau dibakukan oleh pihak perbankan, serta di dalamnya terkandung klausul eksemsi yang memberatkan debitur. Klausul eksemsi sebagai klausul yang ditentukan oleh bank, diterapkan yakni dalam rangka untuk membebaskan tanggungjawab bank terhadap kerugian nasabah debitur baik untuk seluruhnya maupun sebagian, yang sebenarnya kerugian tersebut termasuk dalam lingkup tanggung jawab bank sendiri.

Undang-undang No. 8 Tahun 1999 Pasal 29 dan Pasal 30 tentang perlindungan konsumen menyatakan bahwa: Pasal 29 Pemerintah bertanggungjawab atas pembinaan penyelenggaraan konsumen dan pelaku usaha serta dilaksanakannya kewajiban perlindungan konsumen yang menjamin diperolehnya hak konsumen dan pelaku usaha. Pasal 30 Pemerintah berkewajiban melakukan pengawasan terhadap penyelenggaraan perlindungan konsumen serta penerapan ketentuan perundang-perundangannya diselenggarakan oleh pemerintah, masyarakat dan lembaga perlindungan konsumen swadaya masyarakat.

Berikutnya dalam Pasal 4 huruf b, c, d, Undang-Undang No.8 Tahun 1999 tentang perlindungan konsumen menjelaskan bahwa:

Konsumen mempunyai hak untuk memilih barang dan jasa, serta mendapatkan barang dan jasa tersebut sesuai dengan nilai tukar dan kondisi serta jaminan yang dijanjikan, hak atas informasi yang benar, jelas dan jujur mengenai kondisi dan jaminan barang dan jasa, 
konsumen juga berhak didengar pendapat dan keluhannya atas barang yang digunakan.

Hakekat perjanjian standar merupakan perjanjian yang telah di standarisasi isinya oleh pihak ekonomi kuat, sedangkan pihak lainnya hanya diminta untuk menerima atau menolak isinya. Apabila debitur menerima isi perjanjian tersebut maka ia menandatangani perjanjian tersebut, tetapi apabila ia menolak maka perjanjian itu dianggap tidak ada. Hal ini disebabkan debitur tidak menandatangani perjanjian tersebut. Dalam prakteknya, seringkali debitur yang membutuhkan uang hanya menandatangani perjanjian tanpa dibacakan isinya. Akan tetapi isi perjanjian baru dipersoalkan pada saat debitur tidak mampu melaksanakan prestasinya. Pada perjanjian standar (baku) konsumen berada pada posisi yang kurang menguntungkan atau lemah. Mereka hanya mempunyai hak untuk memilih, menerima atau menolak (take it or leave it). Kondisi ini membawa konsekuensi terbukanya peluang tindakan sewenang-wenang dari pelaku usaha kepada konsumen (Andriany, 2009:2).

Secara eksplisit sulit untuk mendapat ketentuan tentang perlindungan nasabah bank syariah sebagai UU No. 10 Tahun 1998 tentang perbankan sebagian besar pasal-pasalnya terkonsentrasi pada kepentingan bank. Dalam perjanjian atau akad pembiayaan bank syariah, nasabah pada kondisi dilematis, kontrak yang digunakan adalah kontrak standar yang membebani nasabah dengan beragam kewajiban, tanggung jawab dan risiko padahal nasabah juga tidak bisa menawar imbalan yang juga sudah dipatok oleh bank (Mulhadi, 2004: 1).

Selain itu yang khas dari white collar crime yaitu kejahatan tersebut dilakukan si pelaku dengan jalan penyalahgunaan kepercayaan yang diberikan kepadanya dari perusahaan atau masyarakat. Kejahatan kerah putih yang paling banyak terjadi adalah di lembaga-lembaga kepercayaan masyarakat seperti bank, bursa efek, perusahaan asuransi, perdagangan dengan penyerahan kemudian (future trading). Sering dalam perbuatan tindak pidana tersebut terlihat kecenderungan adanya kolusi di antara pelakunya seperti pengusaha dengan penguasa, pemohon pembiayaan (nasabah) dengan pejabat bank, pejabat bank dengan peserta lelang agunan, dan sebagainya. Berbeda dengan kejahatan konvensional, maka white collar crime baru dapat diidentifikasikan setelah selang beberapa waktu hal tersebut di antaranya dikarenakan kerapian pelakunya, sedangkan kejahatan konvensional perbuatannya terlihat lebih cepat dengan nyata dan secara cepat dapat langsung diketahui pelakunya (Untu, 2012: 2). 
ljtihad, Jurnal Wacana Hukum Islam dan Kemanusiaan, Volume 15, No. 1, Juni 2015: 103-118

Sebenarnya, nasabah perbankan (penyimpan dan peminjam) seharusnya mendapat perlindungan yang baik dalam menggunakan produk perbankan. Namun, perlindungan bagi nasabah perbankan baru diimplementasikan secara eksplisit dalam salah satu program dalam pilar keenam Arsitektur Perbankan Indonesia (API) yang diluncurkan awal tahun 2004 (Ritonga, 2014: 12).

Pada 20 Januari 2005, Bank Indonesia (BI) mengeluarkan peraturan baru yakni No $7 /$ 6/PBI/2005 tentang Transparansi Informasi Produk Bank dan Penggunaan Data Pribadi Nasabah, kemudian ditintaklanjuti dengan surat edaran nomor 7/25/DPNP/2005 tanggal 18 Juli 2005. Dalam edaran ini dinyatakan bahwa perbankan harus melaksanakan sepenuhnya PBI dan edaran dimaksud paling lambat 1 Januari 2006. Menyusul peraturan nomor 7/6/ PBI/2005 dan surat edaran 7/25/DPNP/2005, BI juga telah mengeluarkan PBI Nomor 7/7/PBI/2005 tanggal 20 Januiari 2005 tentang Penyelesaian Pengaduan Nasabah, dan PBI Nomor 8/5/PBI/2006 tentang Mediasi Perbankan tanggal 30 Januari 2006. Dengan keluarnya sejumlah PBI dan edaran dimaksud, diharapkan perlindungan nasabah perbankan akan dilakukan dengan lebih baik.

PBI No 7/6/PBI/2005 tentang Transparansi Informasi Produk Perbankan dan Penggunaan Data Nasabah meminta dilaksanakan oleh perbankan dengan memberikan informasi produk secara baik sehingga difahami oleh nasabah dengan efektif. Perlindungan nasabah juga dilakukan dalam beberapa aspek seperti pelayanan purna jual produk perbankan, kesetaraan pelayanan, penjaminan simpanan, penanganan keluhan nasabah serta ketersediaan SOP.

Pemerintah telah mengeluarkan sejumlah peraturan menyusul peraturan mengenai informasi produk bank dan transparansi data nasabah, yakni mengenai pengaduan nasabah dan mediasi penyelesaian sengketa nasabah-bank. Pemerintah juga perlu atauran tentang penggunaan data pribadi mereka oleh pihak diluar core business bank seperti asuransi dan oleh tenaga outsourcing untuk keperluan pemasaran (Ritonga, 2014).

Sesuai Pasal 28 UU No. 21 Tahun 2011 Tentang Otoritas Jasa Keuangan menyatakan bahwa OJK berwenang melakukan tindakan pencegahan kerugian demi melindungi konsumen dan masyarakat yang meliputi: edukasi, pelayanan pengaduan konsumen, dan pembelaan hukum. 
Baitul mal wa Tamwil (BMT) secara fungsi adalah bank karena memang berfungsi sebagi intermediary pihak yang kelebihan dana dengan pihak yang memerlukan dana. Produk-produk pembiayaan dan pengumpulan dana BMT setara atau sama dengan bank syariah. Perbedaan hanya bentuk hukum kepemilikan BMT yang berbentuk Koperasi.

Secara substansi, produk-produk yang dikeluarkan bank syariah termasuk BMT relatif sama dengan bank konvensional, tetapi terdapat satu nilai tambah yang dimiliki bank syariah dan tidak dimiliki bank konvensional, yaitu adanya pembagian keuntungan dan kerugian antara bank dengan nasabah. Prinsip tersebut merupakan senjata utama bank syariah dalam menarik masyarakat di Indonesia yang mayoritas penduduknya beragama Islam. Islam mengajarkan setiap umatnya untuk menjadikan al-Qur'an dan Hadis sebagai dasar atau pedoman hidup sehari-hari. Atau dengan kata lain segala perilaku perbankan syariah harus berdasarkan syariah (Arifin. 2003: 12).

Hal tersebut dijadikan asumsi dasar oleh bank syariah, bahwa sekalipun Indonesia bukan negara Islam, yaitu negara yang berdasarkan hukum syariah, tetapi Indonesia adalah negara yang mayoritas penduduknya beragama Islam. Sebagai negara yang mayoritas penduduknya muslim, maka secara otomatis umat Islam di Indonesia cenderung akan memilih berhubungan dengan bank yang berdasarkan syariah sesuai dengan ajaran Islam.

\section{Asimetri informasi dan kualitas layanan bank syariah}

Nasabah mengharapkan kinerja dari para pelaku perbankan syariah yang lebih berkualitas. Peningkatan kualitas pelayanan yang diberikan oleh bank syariah dapat dijadikan kebijakan alternatif dalam keberhasilan bisnis di dunia perbankan pada saat ini maupun masa yang akan datang. Pelayanan pada nasabah, di mata nasabah mencakup faktor-faktor secara tradisional mewarnai penilaian nasabah atas layanan yang diterima, seperti: kecepatan, ketepatan, keramahan dan kenyamanan.

Di samping faktor-faktor pelayanan, terdapat atribut produk yang juga merupakan titik tolak penilaian bagi konsumen tentang terpenuhi atau tidaknya kepuasan dan loyalitas konsumen yang diharapkan dari suatu produk yang sebenarnya. Dalam perbankan syariah, atribut produk tersebut diidentifikasi sebagai atribut-atribut produk Islam yang bernuansa Islami yang ditawarkan oleh bank. 
ljtihad, Jurnal Wacana Hukum Islam dan Kemanusiaan, Volume 15, No. 1, Juni 2015: 103-118

Setiap nasabah ketika ingin menjaga kehalalan hartanya, bebas dari unsur riba, gharar, maupun judi, serta menggunakan sistem bagi hasil untuk menghasilkan pendapatan, maka dia akan memilih bank yang memiliki atribut produk Islam. Ketika atribut produk Bank Syariah menunjukkan atribut produk yang islami maka nasabah akan merasa puas terhadap produk tersebut. Tingkat kinerja produk dapat diukur atau dilihat pada tingkat posisinya berdasarkan atribut-atribut kunci yang sudah diidentifikasi oleh konsumen. Dengan demikian, atribut produk merupakan titik tolak penilaian bagi nasabah tentang terpenuhi atau tidaknya kebutuhan dan keinginan nasabah yang diharapkan dari suatu produk yang sebenarnya. Atribut-atribut penting yang dinilai konsumen tersebut akan mempengaruhi sikap puas terhadap produk. Atribut produk Islam mempunyai hubungan positif terhadap kepuasan nasabah (Junusi, 2009: 1).

Setiap nasabah ketika memilih perbankan untuk menginvestasikan hartanya pasti mereka memilih kenyamanan kualitas pelayanan bank tersebut. Apabila Bank Syariah yang dipilihnya secara konsisten memberikan kualitas pelayanan yang menyenangkan dibandingkan di Bank Konvensional maka nasabah akan semakin loyal menggunakan bank syariah tersebut dan akan menolak untuk menggunakan bank konvensional. Hubungan antara kualitas layanan dengan loyalitas nasabah dapat membentuk hubungan langsung maupun hubungan tidak langsung terhadap kepuasan nasabah. Setiap nasabah di Bank Umum Syariah mengharapkan kualitas pelayanan yang menyenangkan. Ketika pelayanan yang diberikan Bank Umum Syariah menunjukkan kualitas pelayanan yang menyenangkan dan nyaman maka nasabah akan merasa puas terhadap pelayanan tersebut. Salah satu faktor penting yang dapat membuat pelanggan puas adalah kualitas pelayanan. Secara empiris banyak penelitian dengan latar belakang sampel yang berbeda-beda telah membuktikan bahwa kualitas pelayanan dan kepuasan pelanggan bersifat positif.

Kepuasan yang dirasakan pelanggan menjadi dasar bagi terciptanya pembelian ulang dan loyalitas pelanggan. bank syariah ketika memberikan atribut produk yang Islami dan kualitas pelayanan yang memuaskan sesuai yang diharapkan nasabah maka nasabah akan merasa puas kemudian kepuasannya akan mendorong nasabah untuk tetap loyal menggunakan bank syariah, merekomendasikan ke orang lain, dan menolak untuk tidak menggunakan bank konvensional. Secara umum, kepuasan dan loyalitas mempunyai 
hubungan postif.

Sesungguhnya, secara ekonomi, meningkatnya jumlah konsumen yang loyal akan berdampak pada peningkatan pendapatan perusahaan. Manfaat dari loyalitas pelanggan yaitu ketika sebuah perusahaan secara konsisten memberikan nilai yang terbaik dan memenangkan loyalitas pelanggan maka pangsa pasar dan pendapatan meningkat. Nasabah bank syariah ketika semakin loyal maka akan semakin banyak nasabah yang menginvestasikan hartanya maupun melakukan pembiayaan di Bank Umum Syariah. Nasabah pembiayaan akan berpengaruh pada peningkatan kinerja keuangan bank syariah tersebut (Bakhtiar, 2011: 4).

Hak-hak nasabah perlu perlindungan dari perilaku moral hazard pengelola lembaga bank syariah termasuk BMT. Nasabah dan bank syariah mempunyai kedudukan yang setara karena masing-masing memerlukan. Bank memerlukan dana masyarakat untuk disalurkan dari sisi input. Selanjutnya, bank syariah tidak akan menahan dana tersebut selamanya. Bank akan mengalokasikan dana yang dihimpun kepada masyarakat dalam bentuk pembiayaan. Seringkali, seseorang anggota masyarakat menjalankan dua fungsi sekaligus yaitu sebagai pemilik dana (penabung) dan sebagai penerima pembiayaan.

Perlakuan terhadap nasabah berbeda. Karyawan terkesan lebih ramah terhadap nasabah yang sudah dikenalnya, sehingga nasabah baru akan kecewa apabila melihat perlakuan yang tidak sama tersebut. Kapasitas karyawan dalam komunikasi publik masih kurang misalkan dalam menanggapi suatu permasalahan ada jawaban tidak tahu, atau memutar-mutar tidak menjawab permasalahan yang ada. Transaksi perbakan yang tidak dilakukan oleh karyawan yang berwenang masih ditemui misalkan setor uang ditangani oleh marketing outsourching.

Bank Indonesia Jawa Timur telah melakukan penelitian tentang persepsi masyarakat Jawa Timur terhadap Bank Syariah pada tahun 2006. Hasilnya menunjukkan bahwa persepsi masyarakat santri di Jawa Timur baik yang merupakan nasabah maupun yang bukan nasabah bank syariah, ditinjau dari pendekatan budaya, sosial, pribadi dan psikologis, adalah positif terhadap bank syariah.

\section{Pemahaman masyarakat tentang perbankan syariah}

Permasalahan asimetri informasi di bank syariah tidak hanya menjadi tanggungjawab bank syariah. Kepedulian akan pentingnya pemahaman masyarakat atas transaksi beserta 
ljtihad, Jurnal Wacana Hukum Islam dan Kemanusiaan, Volume 15, No. 1, Juni 2015: 103-118

konsekuensinya dirasakan masih kurang. Banyak nasabah bank syariah yang menginginkan kecepatan layanan dengan mengabaikan konsekuensi dimasa depan yang akan dihadapi dengan tidak mencermati akad secara hati-hati. Padahal, akad dalam perbankan adalah pedoman disaat kondisi baik dan disaat kondisi buruk.

Banyak tantangan dan permasalahan yang dihadapi dalam pengembangan perbankan syariah terutama di Indonesia. Permasalahan yang muncul antara lain adalah rendahnya pengetahuan masyarakat terhadap perbankan syariah terutama yang disebabkan dominasi perbankan konvensional (Bank Indonesia, 2000: 1).

Preferensi masyarakat terhadap keuntungan relatif yang mencerminkan pandangan responden tentang perbankan syariah mempunyai nilai lebih jika dibandingkan dengan bank konvensional. Preferensi terhadap tingkat kompatibilitas yang menunjukkan tingkat kecocokan terhadap sistem perbankan syariah maka terlihat bahwa sebagian besar masyarakat tidak setuju terhadap tingkat kompatibilitas dari perbankan syariah.

Sikap masyarakat yang meliputi sikap terhadap sistem dan produk perbankan syariah menunjukkan bahwa sebagian besar masyarakat tidak mengetahui sistem maupun produk perbankan syariah. Meskipun demikian, ada beberapa daerah yang mempunyai proporsi terbesar berkaitan dengan pengetahuan tentang sistem dan produk bank syari'ah. Sebagian besar responden mempunyai respon yang positif meskipun mereka belum mengenal tentang sistem dan produk-produk perbankan syariah. Masyarakat kurang mengetahui tentang bank syariah terkait dengan produk mapun fasilitas yang ditawarkan karena kurangnya promosi maupun edukasi pasar.

Masyarakat perlu diinformasikan diferensiasi utama produk dan jasa bank syariah dengan yang ditawarkan oleh bank konvensional, baik terkait dengan rational benefit, maupun emotional benefit. Rational benefit di sini terkait dengan hitungan logika berupa keuntungan finansial yang diperoleh nasabah. Pesan utama yang harus disampaikan kepada nasabah adalah bahwa bank syariah memiliki keuntungan finansial yang lebih baik, lebih adil, manusiawi dan memudahkan.

Selanjutnya, emotional benefit di sini lebih kepada keuntungan finansial sekaligus posisi spiritual. Penekanan pada emotional benefit sangat penting bagi nasabah muslim yang sangat mengharamkan riba. Jika emotional benefit ini mengena di benak nasabah efeknya akan 
lama dan melekat kuat sehingga muncul loyalitas nasabah. Di samping itu, perlu ditekankan adanya perasaan tenang dan nyaman bagi nasabah terkait dengan dana yang dipercayakan ke bank syariah, sehingga bank syariah harus benar-benar kredibel dan dapat dipercaya.

Harapannya tentu nasabah akan bergerak dari rational benefit kemudian emotional benefit yang selanjutnya nasabah akan lebih mementingkan spiritual benefit dalam berbank dan berbisnis. Spiritual yang lebih universal, sehingga ajaran agama apapun bisa benar-benar mengakui bahwa sistem perbankan syariah merupakan sistem yang adil, manusiawi, menenteramkan hati, memiliki nilai luhur meskipun berasal dari agama tertentu (Islam). Target konkretnya tentu sampai nasabah dari berbagai agama dan kalangan bersedia menggunakan bank syariah.

\section{Penutup}

Berdasarkan uraian terdahulu dapat diambil kesimpulan sebagai berikut: Asimetri informasi terjadi dalam transaksi bank syariah sejak akad dibuat dan selama transaksi keuangan. Pelaksanaan perlindungan konsumen masih merasa belum adanya keadilan dalam transaksi bank syariah.

Transaksi bank syariah belum efektif dan komitmen dengan yang dimaksudkan UndangUndang Perlindungan Konsumen. Demi kepastian hukum dalam memperoleh perlindungan hukum bagi konsumen maka dalam klausa-klausa perjanjian harus mencerminkan keadilan para pihak agar terwujud rasa keadilan.

Secara substansi belum optimalnya, nilai humanis dalam pemahaman praktisi perbankan syariah. Pemahaman mereka masih terbatas formalistik yang lebih bersifat pragmatis untuk memenuhi kebutuhan praktis yang ada saat ini, belum sampai pada pemahaman syariah filosofis-teoritis dalam rangka membangun akuntansi syariah yang emansipatoris.

Dalam praktiknya hingga kini berdasarkan pengamatan masih sangat jarang korporasi didudukkan sebagai subyek hukum pidana, yang terjadi justru individu atau oknum karyawan di korporasi yang didudukkan sebagai pelaku tindak pidana korporasi.

\section{Daftar pustaka}

Andriany, Heny. "Perlindungan Hukum terhadap Konsumen atas Kasus Ganti Rugi Barang Jaminan pada Perum Pegadaian,” tesis, repository.unand.ac.id, 2009. 
ljtihad, Jurnal Wacana Hukum Islam dan Kemanusiaan, Volume 15, No. 1, Juni 2015: 103-118

Ariccia, Giovanni Del. "Asymmetric Information and Market Structure," IMF Working Paper, 1998, http:/ / wnw.ssrn.com.

Arifin, Zainul. Dasar-Dasar Manajemen Bank Syariah. Jakarta: Alvabet, 2003.

Babczuk, Ricardo N. Asymmetric Information in Financial Market, Introduktion and Applications, Cambridge University Press, 2003.

Bakhtiar, M. Rifki. "Pengaruh Atribut Produk Islam dan Kualitas Pelayanan terhadap Tingkat Pertumbuhan Pendapatan dan Return on Assets (ROA) dengan Kepuasan Nasabah dan Loyalitas Nasabah sebagai Variabel Intervening (Studi Empiris Pada Bank Umum Syariah di Indonesia)," Skripsi, Universitas Diponegoro, 2011.

El Junusi. "Pengaruh atribut produk Islam, komitmen agama, kualitas jasa, dan kepercayaan terhadap kepuasan dan loyalitas nasabah (Studi Kasus di Bank Muamalat Semarang)", Skripsi, Universitas Diponegoro, 2009.

Gaul, Lewis, Viktors Stebunovs. "Ownership and Asymmetric Information Problems in the Corporate Loan Market: Evidence from a Heteroskedastic Regression," 2008.

McDonald, James E., "Asymmetric Information: The Case of Bank Loan Commitments," Journal Of Financial And Strategic Decisions. Vol. 7 No. 3 Fall 1994.

Mulhadi, dkk. Asas Perlindungan Nasabah Debitur Berdasarkan Sistem Bank Syariah. 2004, USU repository.

Peraturan Bank Indonesia No 7/6/PBI/2005 tentang Transparansi Informasi Produk Bank dan Penggunaan Data Pribadi Nasabah.

Peraturan Bank Indonesia Nomor 7/7/PBI/2005 tentang Penyelesaian Pengaduan Nasabah.

Peraturan Bank Indonesia Nomor 8/5/PBI/ 2006 tentang Mediasi Perbankan.

Ritonga, Jhon Tafbu dkk., "Perlindungan Nasabah Perbankan di Sumatera Utara," Paper, http.www.google.com. diakses 2 November 2014, 12.28 WIB.

Santoso, R. Rachardjo Boedi. "Perlindungan Hukum Nasabah Bank Syariah Berkaitan dengan Pelaksanaan Pengawasan oleh Bank Indonesia," tesis, eprints.undip.ac.id, 2009.

Syahdeini, Sutan Remy. Perbankan Islam dan Kedudukanny a dalam Tata Hukum Perbankan Indonesia. Jakarta: Graviti, 1999.

Undang-Undang Nomor 10 Tabun 1998 tentang Perubahan Undang-Undang Nomor 7 Tabun 1992 tentang Perbankan.

Undang-Undang Nomor 8 tabun 1999 tentang Perlindungan Konsumen.

Undang-undang Nomor 21 Tabun 2008 tentang Perbankan Syariab

Undang-Undang Nomor 21 Tabun 2011 tentang Otoritas Jasa Keuangan

United Nations, The United Nations Guidelines for Consumer Protection, 2012. 